\title{
2 Understanding Legal Pluralism in Water and Land Rights: Lessons from Africa and Asia
}

\author{
Ruth Meinzen-Dick ${ }^{\mathbf{a n d}}$ Leticia Nkonya ${ }^{\mathbf{2}}$ \\ ${ }^{1}$ International Food Policy Research Institute (IFPRI), Washington, DC, USA; \\ e-mail: r.meinzen-dick@cgiar.org; ${ }^{2}$ Department of Sociology, Anthropology and Social \\ Work, Kansas State University, Manhattan, Kansas, USA; e-mail: lenkonya@ksu.edu
}

\begin{abstract}
Water rights, like the underlying resource itself, are fluid and changing; they necessarily connect people and they can derive from many sources. Much of the property rights literature has focused on rights to land but, as water rights are now receiving increasing attention from scholars and policy makers in developing countries, it is useful to examine the differences and similarities between land and water rights - as well as the linkages between the two. Without an understanding of the range and complexity of existing institutions that shape water use, efforts to improve water allocations may be ineffective or even have the opposite effects from those intended in terms of efficiency, environment, equity, empowerment and conflict reduction. Reforms need to carefully consider the range of options available. This chapter reviews the multiple sources and types of water rights and the links between land and water rights, using examples from Africa and Asia. It then examines the implications for conflict and for water rights reform processes.

Keywords: water rights, land tenure, legal pluralism, customary law, conflict management, Africa, Asia.
\end{abstract}

\section{Introduction}

Two images are often associated with the term 'property rights': (i) fixed stone walls - immobile, permanent and restricting access to the resource; or (ii) a title deed - a piece of paper with a big seal affixed in a government office. Neither of these images, deriving from the European tradition on land, is very helpful in understanding water rights, particularly in Africa and Asia. Water rights, like the underlying resource itself, are fluid and changing; they necessarily connect people and they can derive from many sources besides the government. As water rights are now receiving increasing atten- tion from scholars and policy makers in develop ing countries, it is useful to examine the differences and similarities between land and water rights - as well as the linkages between the two.

A starting point for this analysis is to consider why property rights matter, and why attention to water rights has lagged behind attention to land rights. Reasons given for attention to property rights are often addressed under four 'E's and a 'C': efficiency, environment, equity, empowerment and conflict reduction.

- In terms of efficiency, the arguments are often made that secure property rights are needed to provide incentives to invest in a 
resource. For water, this often means developing and maintaining the infrastructure, such as a well or an irrigation canal.

- Environmental arguments are closely related: property rights provide an incentive to protect the resource and, without property rights that are enforced, resources often become degraded.

- Equity relates to the distribution of the resource, and can be defined in terms of equality of access, particularly for meeting basic needs, or in terms of distribution of rights in proportion to the investments that people make, or some combination thereof. The way rights are defined determines whether people are included or excluded in the control of a vital resource for their lives. Holding property rights is thus empowering to individuals or groups, particularly control rights that recognize authority over how the resource is managed.

- Clearly defined rights are also held to reduce conflicts over resources during scarcity, which is a matter of growing concern with discussions of 'water wars'. 1

Given this importance of property rights and of water, why has there not been more attention given to rights over water? The induced innovation hypotheses argue that establishing effective property rights is costly so, as long as a resource is abundant, there is little incentive or need to define rights over it but, with increasing demands and scarcity, there is pressure to define rights (Alchian and Demsetz, 1973). This is seen in African history, where 'frontier' areas with low population densities have generally had more loosely defined land rights than areas of high population densities and, as populations increase, land rights become more specific (Besley, 1995; Otsuka and Place, 2001).

However, while changes in land tenure institutions are more familiar, studied and debated, changes in water tenure have received less attention. Nevertheless, we also see that where water is plentiful, people often do not even know or care who else may be sharing the same river, lake or aquifer. As populations grow, demands on water rise, for household use, agriculture and industry. Those who use water are increasingly affected by the actions of other people. Coordination becomes more complex and more crucial. In one way or another, water rights institutions, and expectations about what claims to water are socially accepted as legitimate, are constituted by such competition, influencing people's ability to obtain water.

However, water has several properties, meaning that water rights cannot be determined in exactly the same way as rights to land and other resources. Water is mobile, and most water use depends on flows. After water is diverted, some evaporates or is transpired by plants, but much water also runs back through surface channels and aquifers to be reused further downstream. Cultivation of crops, planting or cutting of trees, and other changes in land use transform the quantity and timing of water flows into and out of aquifers and rivers. While much land is dedicated to a single use, almost all water has multiple overlapping uses and users. All uses not only withdraw some water, but also add something to the water that affects the quality for users downstream, and changes in water flows affect not only human uses but also animals and the broader environment. Rights to water and the consequent patterns of use concern not only how much water is withdrawn but also water quality and the environment.

The slippery nature of water itself makes it more difficult to define water rights because of the need for so much specificity: who can use how much water from what source, when and for what purpose? This specificity, in turn, combined with the fugitive nature of the resource itself, increases the costs of monitoring and enforcing water laws. Instead of establishing rights once and for all, effective water rights require active management of the resource and attention to many different aspects of its use, including quality and quantity, in different places and times.

Improvements in water rights institutions can help reduce poverty, improve economic productivity and protect nature, but these lofty goals are often not achieved. Efforts to improve water allocations may be ineffective or even have the opposite effects from those intended. In this chapter, we argue that to be effective, reforms need to be grounded in a good understanding of social institutions that shape rights to water; additionally, a careful assessment of the options available for improving water 
management should be made, and a willingness shown by those involved to experiment, adapt and learn from experience. The diversity of culture, environment, economic activities and other conditions means there is no one best way to improve water rights and water allocation institutions. The best route to better water management depends on where you are starting from, with many pathways available (Bruns and Meinzen-Dick, 2005).

From this standpoint, the increasing attention to water rights in Asia and Africa is very encouraging, particularly those efforts that seek to address the intricacy of rights over this complex resource. The remainder of this chapter examines some of these complexities, and lessons that can be drawn, not only for water governance in those regions but for other regions and other resources as well. We first review the multiple sources and types of water rights and the links between land and water rights, before examining the implications for conflict and water rights reform processes. Most of the emphasis in the chapter is on how water rights affect people, and hence we focus on the local level, but the concluding section on reform processes also addresses water rights at larger levels.

\section{Legal Pluralism in Water Rights}

Property rights can be defined as: 'the claims, entitlements and related obligations among people regarding the use and disposition of a scarce resource' (Furubotn and Pejovich, 1972). Bromley (1992, p. 4) points out that: 'Rights have no meaning without correlated duties ... on aspiring users to refrain from use.' This means that property rights are not a relationship between a person and a thing but are social relationships between people with relation to some object (the property). Particularly in the case of water, rights also have corresponding duties that apply to the holder of those rights - usually to use the water and dispose of wastes in a certain manner, and often to provide money, labour or other resources in maintaining the water supply.

The crucial point is that property rights are effective (legitimized) only if there is some kind of institution to back them up. In many cases, the state is a primary institution that backs up property rights, but this is not necessarily the case. Irrigation or other water development projects generate their own rules and regulations, which constitute yet another type of 'water law'. Most religions also have precepts relating to water that can provide the basis for entitlements or obligations regarding water. Particularly in the case of water rights, we find many examples of customary law (which changes over time) that is backed by local authority and social norms. User groups may define their own rules for a water point.

At the other end of the scale, international treaties such as the Ramsar convention generate yet another type of law that can provide a basis for placing claims on water resources, e.g. to prevent wetlands from being developed. Particularly in Africa, where so many countries share in international river basins, treaties and other international laws are relevant to the allocation of these shared waters.

The pluralism of water law is further increased because each of these types of law especially state, customary and religious - may itself be plural. Government land laws often contradict water acts. Many communities have different ethnic groups living side by side and using the same water, but having different traditions regarding its use. In particular, many sites have farmers and pastoral groups, with different ways of life and ideas on water. The mix of religions adds to this plurality. All of these types of law will be interpreted differently in different places, generating a plethora of local laws.

These different types of water laws are not neatly separated; rather, they overlap and influence one another. Nor are all equally powerful - their influence will vary. Figure 2.1 illustrates these overlapping types of law, which can be thought of as force fields, with variable strengths (Meinzen-Dick and Pradhan, 2002).

For example, customary law may be very strong and state law virtually unknown or irrelevant in a remote community with low migration and low penetration of state agencies but, in a heterogeneous community with high migration rates in the capital city, customary law may be much weaker than state law (as illustrated in the Nyando basin, Kenya, by Onyango et al., Chapter 11, this volume). In the case of rural land rights in Africa, Bruce and Migot-Adholla 


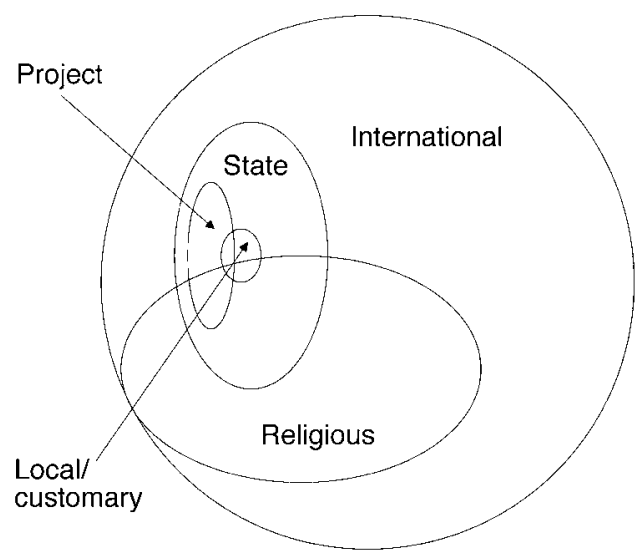

Fig. 2.1. Overlapping legal orders relating to water (from Meinzen-Dick and Pradhan, 2002).

(1994) found that customary land tenure arrangements provided just as much tenure security as government-issued title to the resource. Given the even higher costs of enforcing water rights (compared with land rights) and the limitations of government agency capacity, especially in most rural areas, customary law, backed by local norms and community sanctions, may also be as effective as state law as a basis for claiming water rights in many parts of Asia and Africa.

\section{Bundles of Rights}

As with rights over land or trees, water rights are not usually homogeneous 'ownership' rights that permit one to do anything with the resource, but they may rather be considered as bundles of rights that may be held by different parties. Indeed, because of the complex interrelations between these individual rights and rights-holders, they could even be considered as a 'web of interests' (Arnold, 2002, cited in Hodgson, 2004). The exact definition of these bundles varies, but they are often grouped into two broad categories: (i) use rights of access and withdrawal; and (ii) decision-making rights to regulate and control water uses and users, including the rights to exclude others, manage the resource or alienate it by transferring it to others (Schlager and Ostrom, 1992). To these may be added the rights to earn income from a resource, which Roman legal traditions have referred to as usufruct rights (see also Alchian and Demsetz, 1973). Rights to earn income from a resource (even without using it directly) can be separate from the use and management of the resource, as when government departments collect revenue from water users or when individuals or communities collect a charge from others who use water - a factor that is increasingly important in the context of water transfers.

An example from Kiptegan, a spring protection site in the Nyando basin of Kenya, illustrates this:

- Because of strong local norms that no one should be denied basic water needs, anyone has the right to withdraw water from the pipe below the spring for drinking.

- People may also use water for their cattle, but only from the cattle trough, and they are expected to help keep the trough clean.

- Those community members who have paid some of the cost of developing the spring protection are entitled to a higher level of service, including, if hydrologically feasible and they have paid for it, a piped water supply to meet domestic needs and some small garden uses at their homestead, and to have a say in selecting committee members.

- The members of the committee, who provide additional time and labour, also have decision-making or control rights, including decisions on who can join or who is excluded from the user group, and how the spring and its infrastructure will be managed. They also collect fees from the group members, but do not earn income from this themselves.

These represent a blend of customary law, 'project law' (in the form of rules developed with external assistance when the spring was protected) and rules developed and modified by the user group.

While the exact definition of these bundles of rights varies from place to place, we find several common elements in many water laws in Africa:

- The state generally claims some kind of ultimate 'ownership' rights over water, which may not be felt at all at the local level, or it may require that individuals or groups who want to use or develop a water source need 
to get some kind of permission from the state.

- There are widespread notions that anyone is entitled to water for 'primary uses', which are usually interpreted as basic domestic needs, as well as needs for household gardens, but may include other productive livelihood needs. Islamic law has formalized this as a 'right to thirst' for people and animals. Indeed, many African societies recognize water needs of animals as well as people. As one Kalengin proverb in Kenya says: 'Even the hyena is entitled to water', with the implication that no one can be denied water (Onyango et al., Chapter 11, this volume).

- While basic use rights are strong, they are also usually quite flexible. Rather than being clearly defined in terms of who can draw how much water, access rights are socially negotiated, either individually or by groups, depending on changing local circumstances (Witsenburg and Adano, 2003). In rangelands, Ngaido (1999) discusses the importance of access options for people to use another individual's or group's land and water resources under conditions like drought, which provide a measure of resilience against ecological stress. Cleaver (1998, p. 351) reports a similar pattern for domestic water in Zimbabwe: 'As a precaution against drought, women rarely rely on one source of water but maintain access to a number of different supplies, often through reciprocal social networks. Incentives to cooperate may therefore be indirect and relate to the need to maintain good relations with neighbours and kin in a more general sense.'

- Control rights of management and exclusion are often held by the local chiefs, groups or individuals who developed the source. The effectiveness of these management authorities in setting and enforcing the rules and in maintaining the source varies greatly, as does the extent to which they are participatory or autocratic. Indeed, effectiveness and decision-making practices are related. In Burkina Faso, McCarthy et al. (2004) found that where the chiefs made decisions in collaboration with community members, rather than by themselves, there was a significantly higher cooperative capacity, which led to better resource outcomes. Similarly, in Zimbabwe, Cleaver (1998, p. 355) reported: 'Critical decisions about the rationing of water from particular sources are only successfully enforced in those communities where the decision has been taken at a meeting of the whole community rather than a committee alone. Consensus may enhance collective management since it reduces the need for compulsion, monitoring, and sanction.'

- Most state, customary and religious laws do not grant alienation rights (to sell, give away or otherwise transfer one's rights to someone else)..$^{2}$ More people can be allowed in, but there is no profit to individuals in giving up their rights to water.

Broad patterns of water rights in Asia show a number of similarities, with the state claiming ownership of water. Customary and religious laws also emphasize that all people should be given water for basic domestic needs, although water use for even basic garden irrigation is often more restricted. The state or local farmer groups exercise control rights over how the irrigation systems and their water are used. However, even within systems that have highly formalized rules, access to water is socially negotiated, either among communities or between communities and government agency staff (for examples, see Pradhan et al., 1997; Bruns and Meinzen-Dick, 2000). There are some informal water markets, especially for groundwater, by which those with wells can sell water to other farmers or to industries, but these are generally 'spot markets', not long-term transfer or alienation of the underlying water rights (Easter et al., 1998).

\section{Types of Water Rights}

As with other types of property rights, water rights can be broadly classified as public, common or private property, according to who holds the rights and, particularly, the decisionmaking rights of allocation, which lie at the heart of water rights (Bruns and Meinzen-Dick, 2000, 2005; Paul, 2003).

Public water rights are rights held by the state where the government allocates rights to users. Many countries adhere to some form of 
Public Trust Doctrine, a principle dating back at least to Roman law, which maintains that the state holds navigable waters and certain other water resources as common heritage for the benefit of the people. Under this doctrine, control over water is an aspect of sovereignty, which the state cannot give up (Ingram and Oggins, 1992). The government can assert its rights over water by controlling the water allocation directly through government agencies, or by acting as a licensing or leasing agent for granting water rights (Paul, 2003). In Zimbabwe for example, the water reform in the 1990s declared all the water to be the property of the state.

People can get water rights by acquiring water permits, which give them legal licence to use but not own water. Water permits are issued in consideration of the needs of the applicant and the expected benefits of the proposed water use (Latham, 2000; Mtisi and Nicol, 2003). In Mozambique, the Water Act of 1991 regards water as a public good. People cannot have private ownership of water sources but can obtain rights to use water by acquiring a water licence (Vaz and Pereira, 2000). Water licences are granted for a period of 5 years and are renewable. The use of water for primary needs like small irrigation, domestic use and watering of livestock is free.

Common water rights refer to communal water rights where water can be used by people in ways that are specified by some community. For true common property, some form of community or user group should have rights to allocate water at some level, e.g. in specifying who may or may not use the water and in what ways, as seen in many farmer-managed irrigation systems in Asia (Tang, 1992). In most African customary water laws, water from natural resources is considered as a community property and private ownership of such water is not recognized (WFP, 2001).

Private property rights are rights held by an individual or legal individuals like corporations (Bruns and Meinzen-Dick, 2005). With regard to water, it is generally only use rights that are recognized for individuals, particularly permits or licences that give an individual a right to use water in certain ways (Paul, 2003). In Botswana, for example, people do not need to acquire water rights if they are using the water for domestic purposes or for watering livestock. However, they are required to obtain water rights if they are using the water for irrigation or commercial purposes. In some cases, private rights go beyond just use rights, to include the rights to allocate the water, as in Chile's tradable water rights systems, in which a rightholder can transfer that water to others through sale or lease.

Although there are individual use rights in Africa, private water allocation rights are not widespread. There are some sources such as shallow wells or small dams that are considered private, in which the right-holder has the right to allocate water from that source. In the case of a private water source like a well, an individual is required to obtain land rights to be able to construct a well on a particular piece of land. After the well has been constructed, an individual holds the rights to both the land and water (Carlsson, 2003). Private water rights are also widely observed for groundwater in Asia, and farmers under farmer-managed irrigation systems in Nepal and Indonesia may have private rights to a share of the water in those systems.

In most treatments of property rights, these types of rights are contrasted with open-access situations in which anyone has unrestricted use of the resource. There are no specific rights assigned to anyone and no one can be excluded from using the resource. It is the lack of rules in open-access situations that is seen as contributing to the 'tragedy of the commons', wherein resources degrade because of lack of control over their use or lack of incentives for investment in their provision (Bromley, 1992).

Thus 'open access' has taken on a very negative connotation in much of the resource management literature. However, many discussions of African water rights use the term 'open access' with a positive connotation, which others might associate with the notion of human rights to water (e.g. Gleick, 1999). In African countries, the notion of free access is also applied to some rangelands, rivers and streams (FAO, 2002). Many of these notions were developed under conditions of low population densities, and may not stand up to increasing scarcity and competition. In practice, there are often some forms of restrictions on the 
use of the resource. It is important to address the questions of who will manage the resource, how well and why, whether they cannot exclude others and what consequences these have for the state of the land and water as they come under pressure. However, it is also important to recognize the value placed upon 'open access' to water for all, and to seek ways of accommodating this for growing populations.

Although these different property rights regimes can be distinguished analytically, in practice they often overlap. The state may claim ultimate ownership of the resource, but recognize communal rights over water in a stream and open-access primary use rights for outsiders. When that same water percolates into the water table and is accessed through a well, it may be considered the private right of the person who built the well.

South Africa provides an illustration of these overlapping property rights regimes, and how they change over time. During the apartheid era, state water law was based on the UK common law principle, which gave use and control rights over water to those who owned the overlying land. Thus, groundwater, springs and even small dams on a farm were effectively private property. However, the customary law of most black communities held that there is no private control of water, but the community leader such as the village chief had the right to control and determine the use of water resources for the benefit of the whole community (Tewari, 2002).

The new government reformed water rights through the National Water Act (Act 36 of 1998). This Act declared that the state is the guardian of all water resources in South Africa, but it also incorporated the African customary view on water rights by declaring water to be a public resource belonging to the whole nation and requiring to be available for common use by all South African citizens. All water required for basic human needs like drinking is guaranteed as a right (RSA, 1998; Perret, 2002). Under this Act, people cannot own water but can be granted water use rights through a licensing system, which requires users to pay for it. The money generated from water use charges is used for water service and management costs (Tewari, 2002; Farolfi, 2004). Individual water users are authorized to have water use rights without any payment, registration or licensing if the water is taken for reasonable use for domestic purposes, small gardening and for animal watering. If the water is used for commercial purposes, then individuals are required to obtain a legal entitlement or licence to use water. Through the licensing system, an individual is granted water use right for a maximum of 40 years subject to renewal (Perret, 2002).

Regulations to public water rights are meant to control water use and to resolve problems that might occur as a result of overuse, and to resolve conflicts as results of competing uses. There are thus public rights to regulate the resource, collective rights of all to use water for basic needs and private individual use rights under licences.

\section{The Relationship Between Land and Water Rights}

Much of the current attention to water rights reform now is directed at investigating ways of making water rights separable from rights over land. This particularly applies to well-publicized cases in western USA, Chile and Australia, where growing demand for water for non-agricultural uses in cities and industries creates pressure to transfer water away from agriculture. However, from the point of view of many European statutory laws, water rights have been a subsidiary component of land rights (Hodgson, 2004). In much of Africa and Asia it is hard to identify the water rights because they are intrinsically linked to land. African customary land rights, in turn, depend on social relations - membership in communities or relations with land-allocating chiefs, for example. Indeed, in Ramazzotti's (1996) review of the ethnographic literature on customary water law, most of the information about water rights came from discussions of land law or the institutions of chieftaincies, demonstrating how water rights are embedded in both land tenure and social relations.

Two very different environmental conditions - wetlands and semi-arid rangelands - illustrate the linkages between land and water rights. In wetlands, control over land also gives control over water. Here, land is scarcer than water, 
and hence it makes sense to concentrate on the allocation of land. By contrast, in dry areas, water rights are the key to the control and use of land for pastures. Access to water points opens up the possibility of using large areas of grazing land for migratory pastoralists. ${ }^{3}$ Enclosing a water point can make pastoral production - and even the lives of the pastoralists - unviable.

Keeping animals often overlaps with other land (and water) uses. At the more humid end of the spectrum, animals may be raised in agricultural areas, either by the farmers themselves or by pastoralist households. While there can be complementarity in resource use by letting animals graze on fallow fields, thus providing manure in exchange, there is also potential for conflict, especially where cattle must pass by or through growing fields to get to water. In the Kirindi Oya irrigation system in Sri Lanka, the irrigation development displaced pastoralists from land and did not provide enough alternative watering points for the cattle. Although the cattle farmers' association was included in irrigation Project Management Committee meetings to address cattle damages to crops as they walked through the system to get water, they were not included in the decision making about water allocation to ensure that their needs were met (Meinzen-Dick and Bakker, 2001).

At the drier end of the spectrum, there are important overlapping uses between pastoralists and wildlife that are particularly important in Africa. The interactions between humans, livestock and wildlife have often been studied in terms of land, particularly where parks or reserves are created for wildlife, excluding the people and their animals, but the interactions and even conflicts are often over water, particularly where tourism is developed entailing consumption of large amounts of water, or where fences are used to prevent people from accessing water points, thus denying basic needs.

The principles of interconnected land and water rights are important in understanding both wetlands and drylands, which are particularly important resources in Africa. But even in irrigation systems, land rights are key to obtaining water. There are clearly demarcated areas of land entitled to receive irrigation water. In South India, for example, land is even classified according to whether it is supposed to receive one season of irrigation per year or two, and land values and taxation rates differ accordingly. The development of many irrigation projects has also disrupted land tenure arrangements by expropriating the land to be irrigated, and then reassigning plots in the new system.

This is illustrated in van Koppen's (2000) study of the development of irrigation systems on bas fonds (wetlands) in Burkina Faso: women had held relatively strong use, decision making and even full ownership rights over the bas fond, where they cultivated rice. However, the project initially ignored the fact that women were the landholders, and assigned 'household' plots to the male heads of households, thereby weakening women's rights - an example of project law and customary law clashing. The result was a fall in productivity despite the 'improvement' of the technical infrastructure, because the underlying institutions - including not only property rights but also intra-household relations - were disrupted. Later sites under the project corrected this by involving the women in the land allocation.

In other cases of irrigation development, the state has expropriated all land in the area to be irrigated, and then reassigned (often smaller) plots within the irrigation system, as in Kenya, Malawi and Zimbabwe, for example. The result may be stronger water rights, but weaker land tenure security, as the farmers cultivating irrigated plots often shift from holding relatively strong customary use rights to their land to being 'tenants' on government land, and subject to the threat of eviction for failure to cultivate in prescribed ways, which often include growing specified crops.

Thus, farmers not only lose many decisionmaking rights over their land but also face uncertainty about the duration of their rights. And, because they often cannot transfer or sell their land in the irrigation scheme, they do not benefit from any improvements. This contrasts with the situation in much of Asia, where farmers generally have ownership rights to land within irrigation schemes, which provide for much greater security of tenure and a long-term view of irrigated production.

Even where land and water are not strongly connected for productive purposes (as they are for cultivation or herding), there are vital links 
between land and water rights. In Kenya, for example, there are strong norms specifying that everyone has rights to use water. However, much of the land has been privatized (Onyango et al., Chapter 11, this volume). In the Nyando basin, land-buying companies bought land from large-scale white farmers, subdivided and sold all of the land to smallholders, without regard for the slope or location of the plots relative to water. While no one should be denied water, it was not incumbent upon landowners to allow people and their animals to cross their private land to access the water. The result was that many people had no access to the springs or rivers, and hence could not get water, even for basic domestic needs. The few public access points, such as bridges, became overused. Moreover, communities faced considerable obstacles to developing water sources if they could not control the land, as well.

In the Kiptegan site referred to above, the spring development that benefited the whole community was only possible when, after discussions with World Agroforestry Center and government staff, several men with land surrounding a spring decided to devote that land to the spring protection, planting indigenous trees above it and setting aside an area in which people and cattle could (separately) access the water (Leah Onyango and Brent Swallow, Nairobi, 2004, personal communication).

This spring protection offers a positive example of how the way in which land is used has a major impact on both the quality and the quantity of water resources, and thus on water rights. Unfortunately, negative examples come to mind more readily: (i) cattle tracks or cultivation of hillsides contributing to soil erosion and hence lower water quality and silting up of reservoirs; (ii) pesticide use on farms polluting the streams and groundwater; or (iii) deforestation or reforestation affecting the run-off rates. This linkage between land and water in hydrological units lies at the heart of watershed management programmes. Swallow et al. (2001) point out that these relations are complex, and not all land is equally influential in this: there are particular types of land uses, including wetlands, riverine vegetation and paddy fields, that play critical roles as sinks or filters for water, sediment and other flows. Unfortunately, the property rights to riverine vegetation and wetlands are often not clearly defined, nor are they under the effective control of a management entity that seeks to protect or enhance their watershed functions.

Alongside the burgeoning number of watershed management projects supported by governments and NGOs, land and water rights are being increasingly separated. This is in part fuelled by government structures: land and water are specified in different statutes and administered by different government agencies. Even international and donor organizations recommending policies for land tenure often neglect to mention water, and vice versa. There are also fundamental differences in the conceptualization of land and water rights, with state law often treating land rights in the abstract, without regard for location or topography (as exemplified by the land-buying companies in Kenya). Water rights, by contrast, are usually defined in terms of location, time and use. In reviewing both the functional linkages between land and water, and these divergences, Hodgson (2004) finds that: 'Few formal mechanisms exist in law to ensure a coordinated approach to the allocation and administration of land tenure rights and water rights.'

The growing trend toward integrated water resources management (IWRM) tries to link land and water management in overcoming the divide created by assigning authority over land and water to different government agencies. There are hopeful signs. Kenya's current land tenure and water rights reforms are taking place in parallel, but officials involved in the two processes are at least consulting one another. However, for the integration of land and water rights, state law and institutions may not be the best starting point. Rather, it is useful to look at the ways in which land and water rights and management have been linked in a range of customary institutions, and seek to identify principles upon which appropriate land and water rights linkages can be built.

\section{Water, Rights and Conflict}

Based on property rights theory and experiences with land, it would seem that clearly defined property rights - which, by definition, create shared expectations - would help reduce 
conflict over water, particularly as it becomes scarcer. This notion provides part of the impetus for water rights reforms and formalization (Rogers and Hall, 2003). However logical it may be, it is not necessarily true. When a fixed expectation comes up against a fluctuating resource, that in itself can be a source of conflict. This may explain why customary water rights are so often ambiguous.

In a collection of studies of water conflict in Nepal and India (Benda-Beckmann et al., 1997), a recurring theme is that local norms, which form the basis for claiming water rights, are principles rather than precise rules, subject to recurring negotiation. Indeed, in many of these cases it was the attempts to formalize rights that often triggered conflict, rather than the use of the water itself. The same was found along the Tana river in Kenya, where a government land adjudication programme triggered violence between Pokomo farmers and Orma pastoralists, who had historically shared the resource under more flexible tenure arrangements (Weiss, 2004).

That ambiguous or flexible rules are particularly adapted to situations where the resource is very variable is seen in a study from Marsabit, a dry pastoral area in Northern Kenya. Although there has been recurrent violence and raiding between the different ethnic groups in the area, and both claimed rights to the water points based on different customary principles, Witsenburg and Adano (2003, p. 11) found that conflicts actually decreased, rather than increased, during drought because:

Both ethnic groups claim ownership of the well site, but they both said that the other group had a legitimate claim as well, which they consider in crisis times of drought. Samburu/Rendille herdsmen said that the Boran have a rightful claim, because they have invested time, money and labour to develop the wells, whereas the Boran admit that the Samburu/Rendille have a rightful claim based on their history, having used this water site long before the Boran migrated from Ethiopia in the 1920s ... many [violent] incidents take place at well sites, though not because they want to capture the well or to fight for access to the well. If they would really like to use the well, they would approach the other group peacefully. Instead, they fight at well sites because these are profitable places to raid when there is a concentration of people and animals ... situations of drought and hunger, as in 2000, are different from other situations: they now have a common enemy to fight.

Thus, recognition of the two groups' interrelationships and common need for water mitigates conflict over this vital resource.

Studies from Zimbabwe (Cleaver, 1998; Chikozho and Latham, 2005) have similarly found that customary water rights place a high value on conciliation and conflict avoidance. Although there may be rules governing the use of water, there is a reluctance to punish rulebreakers. 'Approximate compliance' is accepted, taking into consideration hardship circumstances of the rule-breakers. This is similar to adat (customary law) in Indonesia, which considers the intention behind an action as being as important as the act itself when meting out sanctions (Ambler, 1998). Meinzen-Dick and Bakker (2001) also found in Sri Lanka that communities allowed people to use water in ways that were against official government regulations when 'they need it and there is no other source'.

Aaron Wolf (2000) suggests that localized principles used to manage water and mitigate conflict could also provide valuable lessons for those dealing with water at the international level. Based on a study of the Berbers in Morocco and Bedouin in Israel, he suggests that principles such as prioritizing uses and protecting downstream and minority rights can be applied to international waters as well. From our examination of these cases we can suggest an additional principle to draw upon: the value placed on mutual survival, because people recognize that misfortunes that befall others today may affect themselves tomorrow. This leads to a sense that, especially in times of drought, there is a common enemy that competing users should cooperate to overcome.

\section{Implications for Water Rights Reform Processes}

Many countries in Africa have been, or still are, engaged in a variety of land tenure reform processes. Now, due to a range of internal and external pressures, many in Africa and Asia are also embarking on water rights reforms. Comparing the impetus between land and water 
rights reforms, Hodgson (2004, p. 30) finds: 'The concerns of water rights reform, scarcity and sustainability, are quite absent from the land reform debate.' But, on the other hand: 'Generally speaking, water rights reforms have had fewer re-distributive or socio-economic objectives than reforms to land tenure rights. An exception is South Africa whose recently enacted Water Act seeks to implement the two key principles of the 1997 National Water Policy, "sustainability" and "equity"' (Hodgson, 2004, p. 28).

Many land tenure reform programmes (e.g. Kenya's Swynnerton Plan (Swynnerton, 1954)) have imposed Western-style private property with cadastres and title. However, experience has shown problems with this approach in terms of the high costs and potential to exclude many people. Research on customary tenure (particularly in Africa) has also found that customary systems do not necessarily create tenure insecurity that limits investment (Bruce and Migot-Adholla, 1994). Consequently, new donor and government plans take more nuanced approaches, starting with more attention to existing land tenure (e.g. EU, 2004).

Even de Soto, a well-known advocate of land titling and privatization programmes, argues that it is essential to understand the customary rules and social contracts ('people's law') that are already in place before implementing any major reforms:

\section{Outside the West, extralegal social contracts prevail for a good reason: they have managed much better than formal law to build on the actual consensus between people about how their assets ought to be governed. Any attempt to create a unified property system that does not take into account the collective contracts that underpin existing property arrangements will crash into the very roots of the rights most people rely on for holding onto their assets.}

(de Soto, 2000, p. 171)

If that applies to land rights, it is even truer for water.

Yet, water-reform processes are often dominated by (statutory) legal scholars and/or hydrologists, and have not always started with a thorough understanding of existing water rights and governance systems. Programmes of formalizing, registering and individualizing water rights run the risk of creating "cadastre disasters', unless they learn from the experience of land tenure reforms and take into account the range of existing water rights. In the remainder of this section, we examine how an improved understanding of the complexity of existing (pluralistic) water rights could contribute to effective reforms, and how the experiences from land and water rights reforms might inform one another.

It may yet be that the property rights school will be proved right, and rising demands and competition for limited water resources will prompt formalization of water rights in Asia and Africa. These changes are taking place in land rights, both through state and external intervention and endogenously through changes in the customary law itself (Otsuka and Place, 2001). With rising populations and growing per capita water consumption - for domestic uses, intensification of agriculture and industrialization water uses and users are becoming even more interconnected, not just at the local level where face-to-face negotiations are possible, but over large distances, from rural areas to cities, and even across national boundaries. For example, in the Mara-Serengeti basin of Kenya and Tanzania, agricultural development in the upstream areas is affecting the quantity and quality of water available for the pastoralists and wildlife further down, a factor compounded by increasing tourism, which also creates high water demands. Some form of new institutional arrangements is called for to regulate or reconcile these competing demands.

Existing customary institutions are likely to be inadequate where the competing users are from different ethnic or religious backgrounds and where they do not share the same norms and customs. Thus, the emerging water law is likely to be based on state institutions. When the competing users do not even share the same government, then creating some form of international institution is often suggested. But, as these decision-making and regulatory bodies move away from the institutions, based on social relations in which much customary water law is currently embedded, the users affected are likely to have less direct say in the decision making. Just as importantly, they are likely to identify less with the other water users with whom they share the resource, or to understand and respect each other's needs. The lower 
influence on the rules and lower sense of identity with other users are likely to reduce compliance with the rules, unless there is strong enforcement, which is often beyond the capacity of those new formal institutions.

The question is whether the emerging (national or international) governance systems that set and enforce water rights at these higher levels can build on the principles of social relations and personal contact, by including mechanisms for members of different user groups to meet and understand each other's needs. Such 'multi-stakeholder platforms' may take longer in developing the rules, and may seem more costly than to just have 'experts' do the work, but in the long term it may pay off through increased legitimacy, and hence higher compliance at lower enforcement costs.

At the same time, we should not romanticize customary systems. There is ample evidence that customary law frequently reflects unequal power relationships in local communities. Such relationships greatly affect the ways in which land and water are distributed and managed. State law may seek to confer more rights on the less advantaged members of a given community, on paper at least. Formalization of water rights may also be called for to protect the livelihoods of existing users against new uses and users. This is especially relevant as water use increases, bringing local users into competition with other users.

However, there is ample evidence that groups like women or the poor often lose out in processes of formalization, particularly in land titling programmes (Lastarria-Cornhiel, 1997). One reason they lose out is that they often lack the resources (knowledge, time, travel and money) required to acquire security of tenure through the state. But, as the 'force field' of state law increases, the customary security of tenure through social relations can weaken. To understand the barriers that marginalized groups face in getting formally recognized rights, it would be useful for those who develop any water rights registration programmes to literally walk through the whole process with a poor rural woman. Seeing exactly what it would take for such a woman to acquire recognized rights through the state could provide both insights and motivation to modify the system to remove as many obstacles as possible for people like her.

Another reason that the poor lose out is that formal state systems often accord less recognition to the overlapping rights to the resource, on which many poor people rely (Hodgson, 2004). We have seen that both land and water rights have multiple uses and users. These multiple users often have some shared understandings on who, how, when and how much of the resource can be used, the interlinkages between them and perhaps even quality issues. These are often lost in tenure reforms, particularly privatization, because such conditionality is seen to increase transaction costs and hinder the efficient redistribution of property rights. Even when the state declares itself the owner of all resources, as the custodian for all the people, Hodgson (2004) finds that the effect is the denial of customary rights as well as the erosion of local management authority over the resource.

Codification of rights often does not allow for considerations of special circumstances, such as basic livelihood needs, that are typically given substantial weight in customary systems. This is partly due to limitations of state capacity to interpret individual circumstances, but it also derives from the current emphasis on the 'rule of law', which implies that everyone should be treated equally, without special considerations. Reforms of both land and water tenure often have the objective of 'regularizing' all uses of water under the authority of a state agency (Hodgson, 2004) or of 'integrating all forms of property into a unified system' (de Soto, 2000, p. 162). Legal anthropologists who study the multiple types of 'law' that abound in any society would suggest that this is not possible - that pluralism will always persist, in some form. But, even if it were possible to fit all customary law within the ambit of state law, it may not be desirable, because the pluralism in water rights and basis for claims allow for dynamism, for adaptation to varying local circumstances (Berry, 1993; Meinzen-Dick and Pradhan, 2002).

One option that is increasingly used in land tenure reforms is for the state to recognize local authorities, who can set and administer rights within their areas. This builds on both local custom and uses the institutions to back those rights, instead of relying heavily on state appa- 
ratus, which is often costly or ineffective, especially in rural areas. Tanner (2002) discusses some of the challenges that this approach faced in Mozambique, particularly difficulties in codifying many different customary systems, protecting the rights of women (who are strongly disadvantaged under customary land law) and guarding against unscrupulous chiefs.

To this list of challenges should be added variation in the capacity of local leaders and of communities to manage the resource. Effective management of the resource itself is required to make water rights effective and, if the state does not deliver this, then local leadership and collective action are critical. But such local institutions do not function well in every community; hence, devolution of authority over water rights will not work well in all locations, and due attention should be given to local capacity building.

Whatever institutional reforms are chosen, the state cannot simply wave a magic legislative wand or issue an administrative order and expect to automatically change water rights on the ground. Effective changes - from de jure to de facto - require more than changes in the law itself: they need to become widely known, discussed and even debated. South Africa's water rights reforms exemplify this.

There was a prolonged process of public discussion over the Water Act, which not only served to refine the legislation itself but to ensure that it was widely known, so that people could appeal to the new laws to claim their rights and to see that the provisions of the law were implemented. In contrast to other countries in which reforms in water rights legislation have been passed in response to donor requests, but never discussed, the public is aware of South Africa's reforms, which makes implementation much more likely. The next step is to build the capacity of implementing institutions, which may require considerable investment of time, training and other resources, particularly if multi-stakeholder institutions are to be developed (Seetal and Quibell, 2005).

However, it is not only statutory water rights that can be changed. Customary and even religious law also evolve over time in response to changing environmental conditions, livelihoods and even changes in other types of law. Thus, a change in state law can stimulate changes in customary law.

Because of the fundamental importance of water, water rights reforms need to give particular attention to the question of how such changes in state or local law will affect the poor. State law can make special provisions for disadvantaged groups, to which they can appeal. But for this to have any effect requires legal literacy campaigns, so that even illiterate rural women will know of any new rights that they are supposed to be accorded.

Before rushing to formalize water rights, which have often involved either nationalization or privatization, it is important to consider the full range of options, including looking for new forms of property rights that build upon strong customary principles, especially the widespread norms that specify rights to water for basic needs. Here, the international discourse and customary law come together in emphasizing water as a basic human right. However, because water rights are meaningless without an institution to back them, serious questions of how much water can be used will need to be addressed, as well as what incentives there will be for anyone to supply it.

'Open access' to water may be desired (as indicated in many of the local laws) but not feasible. Yet, water rights reforms should strive to ensure that the basic principle is met: that water for basic livelihood needs will be available for all. Both restraint on use and investment in provision are required. Achieving this may require going beyond conventional measures of regulation or economic incentives, to also appeal to norms and values of sharing and caring for others, as well as for the earth. As Mahatma Gandhi reminded us, over 50 years ago: 'Earth provides enough to satisfy every man's need, but not every man's greed.'

\section{Acknowledgements}

This chapter draws upon work done in collaboration with Bryan Bruns, Rajendra Pradhan, Brent Swallow and Leah Onyango, particularly Bruns and Meinzen-Dick (2000, 2005), MeinzenDick and Pradhan (2002) and Onyango et al., Chapter 11, this volume. Esther Mwangi and Stephan Dohrn also gave valuable comments. 
The intellectual input of all these colleagues is gratefully acknowledged.

\section{Endnotes}

1 Although there is considerable talk of 'water wars', in fact there is little evidence of international violent conflict over water. Violence over water is more likely at the local level (Ravnborg, 2004).
2 An exception in customary law is where someone has dug a well or developed a source that is considered private, and can bequeath that source to heirs, e.g. under Maasai tradition (Potkanski, 1994, cited in Juma and Maganga, 2005).

3 In west Asia and North Africa, herders with large flocks increasingly bring water to their animals, rather than the reverse, but the higher costs of fuel and transport, as well as high poverty rates, make this less of an option in most of sub-Saharan Africa.

\section{References}

Alchian, A.A. and Demsetz, H. (1973) The property rights paradigm. Journal of Economic History 16 (1), $16-27$.

Ambler, J.S. (1998) Customary Law (Adat) in Indonesia: Perspectives on Colonialism, Legal Pluralism, and Change. Background paper prepared for the visit of the delegation from the Institute of Folk Culture, National Centre for Social Sciences and Humanities, Hanoi, to Indonesia, 23 May-1 June 1998.

Arnold, C.A. (2002) The reconstitution of property: property as a web of interests. Harvard Environmental Law Review 26 (2), 281.

Benda-Beckmann, F.v., Benda-Beckmann, K.v. and Spiertz, J. (1997) Local law and customary practices in the study of water rights. In: Pradhan, R., Benda-Beckmann, F.v., Benda-Beckmann, K.v., Spiertz, H.L.J., Khadka, S.S. and Azharul Haq, K. (eds) Water Rights, Conflict and Policy. International Irrigation Management Institute, Colombo, Sri Lanka, pp. 221-242.

Berry, S. (1993) No Condition Is Permanent: the Social Dynamics of Agrarian Change in Sub-Saharan Africa. University of Wisconsin Press, Madison, Wisconsin.

Besley, T. (1995) Property rights and investment incentives: theory and evidence from Ghana. The Journal of Political Economy 103 (5), 903-937.

Bromley, D. (1992) The commons, property, and common-property regimes. In: Bromley, D. (ed.) Making the Commons Work. Institute for Self-Governance Press, San Francisco, California, pp. 3-16.

Bruce, J.W. and Migot-Adholla, S. (eds) (1994) Searching for Land Tenure Security in Africa. World Bank, Washington, DC.

Bruns, B.R. and Meinzen-Dick, R. (eds) (2000) Negotiating Water Rights. Sage, New Delhi, India.

Bruns, B.R. and Meinzen-Dick, R. (2005) Frameworks for water rights: an overview of institutional options. In: Bruns, B.R., Ringler, C. and Meinzen-Dick, R. (eds) Water Rights Reform: Lessons for Institutional Design. International Food Policy Research Institute (IFPRI), Washington, DC, pp. 3-26.

Carlsson, E. (2003) To Have and to Hold: Continuity and Change in Property Rights Institutions Governing Water Resources among the Meru of Tanzania and the BaKgatla in Botswana, 1925-2000. Almqvist and Wiksell International, Stockholm.

Chikozho, C. and Latham, J. (2005) The relevance of customary law: Zimbabwean case studies of water resource management. Paper presented at the International Workshop on African Water Laws: Plural Legislative Frameworks for Rural Water Management in Africa, 26-28 January 2005, Gauteng, South Africa.

Cleaver, F. (1998) Choice, complexity, and change: gendered livelihoods and the management of water. Agriculture and Human Values 15 (4), 293-299.

de Soto, H. (2000) The Mystery of Capital: Why Capitalism Triumphs in the West and Fails Everywhere Else. Basic Books, New York.

Easter, K.W., Rosegrant, M.W. and Dinar, A. (eds) (1998) Markets for Water: Potential and Performance. Kluwer Academic Publishers, Boston, Massachusetts.

EU (European Union) Task Force on Land Tenure (2004) EU Land Policy Guidelines. European Union, Brussels.

FAO (Food and Agriculture Organization of the United Nations) (2002) Gender and Access to Land. Land Tenure Studies 4, Food and Agriculture Organization, Rome.

Farolfi, S. (2004) Action Research for the Development of a Negotiation Support Tool Towards Decentralised Water Management in South Africa. Working Paper 2004-01, University of Pretoria, South Africa. 
Furubotn, E.G. and Pejovich, S. (1972) Property rights and economic theory: a survey of recent literature. Journal of Economic Literature 10 (4), 1137-1162.

Gleick, P.H. (1999) The human right to water. Water Policy (1), 487-503.

Hodgson, S. (2004) Land and water - the rights interface. FAO legal papers, Online 36, Food and Agriculture Organization, Rome. Available at http://www.fao.org/legal/prs-ol/lpo36.pdf (accessed 3 January 2004).

Ingram, H. and Oggins, C.R. (1992) The public trust doctrine and community values in water. Natural Resources Journal 32, 515-537.

Juma, I.H. and Maganga, F.P. (2005) Current reforms and their implications for rural water management in Tanzania. Paper presented at the International Workshop on African Water Laws: Plural Legislative Frameworks for Rural Water Management in Africa, 26-28 January 2005, Gauteng, South Africa.

Lastarria-Cornhiel, S. (1997) Impact of privatization on gender and property rights in Africa. World Development 28 (8), 1317-1334.

Latham, J. (2000) Towards an understanding of local level adaptive management: matching the biosphere with the sociosphere. Paper presented at the 1st WARFSA/WaterNet Symposium: Sustainable Use of Water Resources, 1-2 November 2000, Maputo, Mozambique.

McCarthy, N., Dutilly-Diane, C., Drabo, B., Kamara, A. and Vanderlinden, J.-P. (2004) Managing Resources in Erratic Environments: an Analysis of Pastoral Systems in Ethiopia, Niger, and Burkina Faso. Research Report 135, IFPRI, Washington, DC.

Meinzen-Dick, R.S. and Bakker, M. (2001) Water rights and multiple water uses: issues and examples from Kirindi Oya, Sri Lanka. Irrigation and Drainage Systems 15 (2), 129-148.

Meinzen-Dick, R.S. and Pradhan, R. (2002) Legal Pluralism and Dynamic Property Rights. CGIAR SystemWide Program on Property Rights and Collective Action Working Paper 22, IFPRI, Washington, DC. Available at http://www.capri.cgiar.org/pdf/capriwp22.pdf (accessed 3 January 2005).

Mtisi, S. and Nicol, A. (2003) Caught in the Act: New Stakeholders, Decentralisation and Water Management Processes in Zimbabwe. Sustainable Livelihood in Southern Africa. Research Paper No. 14, Institute of Development Studies, Brighton, UK.

Ngaido, T. (1999) Can pastoral institutions perform without access options? In: McCarthy, N., Swallow, B., Kirk, M. and Hazell, P. (eds) Property Rights, Risk, and Livestock Development in Africa. IFPRI/International Livestock Research Institute, Washington, DC, pp. 299-325.

Otsuka, K. and Place, F. (eds) (2001) Land Tenure and Natural Resource Management: a Comparative Study of Agrarian Communities in Asia and Africa. Johns Hopkins University Press, Baltimore, Maryland.

Paul, M.O. (2003) Defining property rights for water marketing. Paper presented at the World Water Congress, International Water Resources Association, Madrid.

Perret, S.R. (2002) Water policies and smallholding irrigation schemes in South Africa: a history and new institutional challenges. Water Policy 4 (3), 283-300.

Potkanski, T. (1994) Property Concepts, Herding Patterns and Management of Natural Resources among the Ngorongoro and Salei Maasai of Tanzania. Pastoral Land Tenure Series No. 6, IIED Drylands Programme, International Institute for Environment and Development, London.

Pradhan, R., von Benda-Beckmann, F., von Benda-Beckmann, K., Spiertz, H.L.J., Khadka, S.S. and Azharul Haq, K. (eds) (1997) Water Rights, Conflict and Policy. International Irrigation Management Institute, Colombo, Sri Lanka.

Ramazzotti, M. (1996) Readings in African Customary Water Law. FAO Legislative Study No. 58, Food and Agriculture Organization, Rome.

Ravnborg, H.M. (2004) Water and Conflict - Lessons Learned and Options Available on Conflict Prevention and Resolution in Water Governance. DIIS Brief, Danish Institute for International Studies, Copenhagen.

Rogers, P. and Hall, A.W. (2003) Effective Water Governance. TEC Background Papers No. 7, Global Water Partnership/SIDA, Stockholm.

RSA (Republic of South Africa) (1998) The National Water Act. Act Number 36 of 1998.

Schlager, E. and Ostrom, E. (1992) Property-rights regimes and natural resources: a conceptual analysis. Land Economics 68 (2), 249-262.

Seetal, A. and Quibell, G. (2005) Water rights reform in South Africa. In: Bruns, B.R., Ringler, C. and Meinzen-Dick, R. (eds) Water Rights Reform: Lessons for Institutional Design. IFPRI, Washington, DC, pp. 153-166.

Swallow, B.M., Garrity, D.P. and van Noordwijk, M. (2001) The Effects of Scales, Flows and Filters on Property Rights and Collective Action in Watershed Management. CGIAR System-Wide Program on Property Rights and Collective Action, Working Paper 16, IFPRI, Washington, DC. Available online at http://www. capri.cgiar.org/pdf/capriwp16.pdf (accessed 3 January 2005). 
Swynnerton, R.M.M. (1954) A Plan to Intensify the Development of African Agriculture in Kenya. Government Printer, Nairobi.

Tang, S.Y. (1992) Institutions and Collective Action: Self-Governance in Irrigation. ICS Press, San Francisco, California.

Tanner, C. (2002) Law-making in an African Context: the 1997 Mozambican Land Law. FAO legal papers, Online No. 26, FAO, Rome. Available at http://www.fao.org/Legal/prs-ol/lpo26.pdf (accessed 3 January 2005).

Tewari, D.D. (2002) An Analysis of Evolution of Water Rights in South African Society: an Account of Three Hundred Years. Working Paper, University of Natal, Durban, South Africa.

van Koppen, B. (2000) Gendered water and land rights in rice valley improvement, Burkina Faso. In: Bruns, B. and Meinzen-Dick, R. (eds) Negotiating Water Rights. Sage, New Delhi, India, pp. 83-111.

Vaz, Á.C. and Pereira, A.L. (2000) The Incomati and Limpopo international river basins: a view from downstream. Water Policy 2 (1-2), 99-112.

Weiss, T. (2004) Guns in the Borderlands, Reducing the Demand for Small Arms. Monograph No. 95, Institute for Security Studies, Pretoria, South Africa.

WFP (World Food Programme) (2001) Water Tenure, Natural Resource Management and Sustainable Livelihood. Natural Resource Management No. 5, International Land Coalition Resource Centre, Rome.

Witsenburg, K. and Adano, W.R. (2003) The use and management of water sources in Kenya's drylands: is there a link between scarcity and violent conflicts? AGIDS/UvA, Amsterdam. Available online at http://www2.fmg.uva.nl/agids/publications/2003/documents/witsenburg_use.pdf (accessed 3 January 2005).

Wolf, A.T. (2000) Indigenous approaches to water conflict negotiations and implications for international waters. International Negotiation 5 (2), 357-373. 